\title{
Campos e pertenças na biolgrafia de um poeta popular: - caso Manoel Camilo dos Santos
}

\author{
Literary fields and belongings in the bio/graphy of a popular poet: \\ the case of Manoel Camilo dos Santos
}

Geice Peres Nunes

Universidade Federal do Pampa (UNIPAMPA)

\begin{abstract}
Resumo: No presente ensaio, desenvolvemos um estudo sobre a poesia popular do Nordeste, centrando-nos especialmente na trajetória bio/gráfica de Manoel Camilo dos Santos e suas tentativas de transcender o espaço do popular por meio de recursos pouco usuais no seu estrato. Para tanto, observamos as ações do poeta-editor, bem como as estratégias utilizadas no conjunto de sua criação artística, datada entre as décadas de $30 \mathrm{e}$ 80 do século XX. Como base teórica, valemo-nos dos postulados de Pierre Bourdieu e suas teorizações sobre o conceito de campo literário.
\end{abstract}

Palavras-chave: Campo literário. Pertencimento. Poesia popular do Nordeste.

Abstract: In this essay, we develop a study on the popular poetry of Northeastern Brazil, focusing especially on the bio/graphic trajectory of Manoel Camilo dos Santos and his attempts to transcend the space of the popular through unusual resources in his stratum. Therefore, we observed the actions of the poet-editor, as well as the strategies used in the set of his artistic creation, dating between the decades of 30 and 80 of the 20th century. As a theoretical basis, we use Pierre Bourdieu's postulates and his theorizations about the concept of literary field.

Keywords: Literary field. Belonging. Northeastern Brazil popular poetry. 
As oito décadas de vida do poeta popular Manoel Camilo dos Santos, paraibano, nascido na cidade de Guarabira, em 1905, e falecido em Campina Grande, no ano de 1987, são capazes de dar uma amostra da literatura de cordel no Brasil, desde seu período áureo até o agudo declínio sofrido na segunda metade do século XX, acentuado pela popularização de novas mídias ${ }^{1}$.

A poética de Manoel Camilo pode ser compreendida por sua construção em sentido duplo que perpassa sua bio/grafia ${ }^{2}$, pois, na qualidade de agente multifacetado do cordel, sua expressão artística possibilita mapear os lugares de pertença do poeta popular no seu espaço de produção literária, assim como as suas aspirações fora dele, quando observamos as linhas de força que orientam o(s) campo(s) literário(s), especialmente no que tange o popular. Nesse sentido, os anos que abrangem a trajetória artística de Camilo evidenciam os seus principais artifícios para frequentar os círculos de prestígio no campo que integrou e, até mesmo, suas investidas conscientes de transcendê-lo ou ultrapassá-lo.

Possuidor de uma produção escrita formada por folhetos populares compostos, especialmente, entre as décadas de 30 e 60; pelo livro Autobiografia do poeta (1979); e pelo manuscrito inédito o livro dos sete episódios (1985), hoje, essas são as composições de Manoel Camilo passíveis de serem reunidas. Apesar de aparentemente abreviada, a tarefa oferece dificuldade: raras vezes um folheto seu é encontrado para venda na sua forma original; sua produção é mais abundante em acervos especializados em literatura de cordel ${ }^{3}$, porém, o grande número é composto mais por repetições do que por variedade de títulos; outra relevante forma de contato se dá por algum exemplar da tiragem de livros impressos pela editora da UFPB; e, por fim, com um acesso mais restrito, o manuscrito de sua autoria pertencente ao acervo da Academia Brasileira de Literatura de Cordel (ABLC), no Rio de Janeiro. Reunindo essa

1 Em História do Brasil em Cordel, Mark Curran (2003, p. 182) destaca que a popularização do rádio à pilha $\mathrm{e}$ da televisão influenciou profundamente no recebimento do cordel pelo seu público cativo. No novo cenário, o sertanejo deixou de lado a antiga prática de comprar o folheto, levá-lo para casa, ouvir uma leitura em voz alta, e passou a ouvir as notícias diretamente pela voz de um locutor. A produção de folhetos, a pesar de persistir, perdeu o caráter de novidade, perdendo paulatinamente a função de jornal do povo.

2 Conceito desenvolvido por Dominique Maingueneau (2001, p. 46) em 0 contexto da obra literária.

3 Durante as pesquisas realizadas no período de doutoramento, coletamos informações no acervo virtual e físico da Biblioteca Central Blanche Knopft, pertencente à Fundação Joaquim Nabuco (FUNDAJ), em Recife; e em acervos localizados no Rio de Janeiro como a Academia Brasileira de Literatura de Cordel (ABLC); o acervo virtual e físico do Centro Nacional do Folclore e Cultura Popular (CNFCP); e o acervo virtual e físico da Fundação Casa de Rui Barbosa. 
produção, o investigador pode se deparar com diferentes etapas da bio/ grafia e, sobretudo, da carreira do artista em que se vê de forma límpida a busca de ascensão e de reconhecimento no campo da literatura culta.

A compreensão da trajetória literária do poeta popular, e seus bastidores, pode ser analisada por duas perspectivas complementares: a da sociologia da arte, de Pierre Bourdieu, e a da crítica literária latino-americana, especialmente nos postulados de Ana Pizarro. Em um sentido amplo, esses olhares permitem compreender a obra (popular ou culta) em sua interação com o seu contexto: na forma de agentes, espaços, meios de difusão, práticas e sistemas. Como obras provenientes de uma determinada cultura, inseridas no tecido da sociedade que as vê emergir, cujas modulações - ou diversidades na unidade - precisam ser observadas (PIZARRO, 1985, p. 18). Portanto, apontam para campos

Campose pertenças na bio/grafia de um poeta popular literários plurais e para culturas (e produtos) plurais.

$\mathrm{Na}$ crítica contemporânea, avaliando bastidores de produções artísticas, assim como os diferentes campos literários, Pierre Bourdieu destaca os mecanismos das estratégias de consagração por meio da arte. É a partir desse lugar que defende que

\footnotetext{
existir socialmente é ocupar uma posição determinada na estrutura social e trazer-lhe as marcas, sob a forma, especialmente, de automatismos verbais ou de mecanismos mentais, é também depender, ter e ser tido, em suma, pertencer a grupos e estar encerrado em redes de relações que tem a objetividade, a opacidade e a permanência da coisa e que se lembram sob a forma de obrigações, de dívidas, de deveres, em suma, de controles e sujeições (1996, p. 42-43).
}

À medida que nos aprofundamos na produção de Camilo, somos induzidos a lançar "um olhar que individualiza o poeta e que traz à tona aspectos que desfazem a ideia generalista de que a poesia popular é um todo maciço" (NUNES, 2014, p. 116). A obra de Camilo comprova operar dentro da lógica do campo literário quando se entende que sua existência artística está atrelada a ter uma posição de destaque na sua arte popular a ponto de ansiar transcendê-la. Para o poeta popular, as estratégias para esse fim lhe chegam como arremedos dos "automatismos verbais" e dos "mecanismos mentais" que tenta fazer uso, porém, calcados em uma retórica ultrapassada ou mesmo anacrônica, que revela a 
passagem de um produzir singelo ao artificioso rebuscamento como um apelo aos potenciais leitores cultos. Visualizamos composições em que a grandiosidade de dar forma ao anódino se perde na eloquência artificial em que o poeta se esforça para expressar-se. Assim, a prosa de Camilo se compõe por uma verborragia que parece ser compreendida por ele como uma exigência, talvez por isso, na tentativa de ser reconhecido, lido e levado a sério no campo de prestígio, rechaça o simples e modifica totalmente o estilo que lhe caracterizou nas primeiras produções versadas.

Geice Peres Nunes

É corrente que o contato com a poesia de Manoel Camilo se dê, inicialmente, por meio de seus versos de maior destaque: Viagem a São Saruê $\left(19--^{4}\right)$. Por si só, o folheto carrega questões muito curiosas acerca do repertório de leituras, da formação/educação do poeta popular, bem como de precursores do referido cordelista: há uma incontestável recriação do mito do País da Cocanha (Pays de Cocagne), um espaço utópico, com traços do maravilhoso e de um imaginário de fartura, delineado em diversas sociedades e cronologias, desde a Idade Média até a literatura popular do século XX no Brasil, conforme mapeou Hilário Franco Júnior (1998).

Viagem a São Saruê (19--) nos reporta a um universo utópico, recriado em forma de sextilhas heptassilábicas por meio de um lirismo em nada excedente: "Eu que desde pequenino/ sempre ouvia falar/ nesse tal São Saruê/ destinei-me a viajar/ com ordem do pensamento/ fui conhecer o lugar" (SANTOS, 19--, p. 01). O espaço representado nos versos detém uma sensorialidade visual, táctil, olfativa, evidenciada em pés de conteúdo descritivo em que - assim como o Marco Polode Cidades Invisíveis (2002), recriado por Ítalo Calvino - ao visitar o lugar de sonho, enquanto voz poética, Camilo delineia sensações e constatações daquilo que apreende com o olhar e conjectura a partir de sua posição social: "Avistei uma cidade/ como nunca vi igual/ toda cobertura de ouro/ e forrada de cristal/ ali não existe pobre/ é tudo rico em geral" (SANTOS, 19--, p. 03). Como criação poética, apesar de apresentar um espaço sui generis, os recursos de linguagem empregados concentram a referencialidade típica dos versos populares sertanejos; o teor narrativo comunica sem obscurecer qualquer sentido, garantindo que os efeitos e sensações

4 Folheto sem data. Supomos que tenha sido produzido na década de 50, por citações em entrevistas e outros documentos que reportam a produção ao início dos 50, como na Revista Bando(1954) e a entrevista a Orígenes Lessa, em 1954, publicada em A voz dos poetas (1984). 
sejam partilhados com o leitor/ouvinte. Nesse aspecto, em seu contexto de difusão, a originalidade do poema está no intertexto medieval adaptado à vida sertaneja, na reconstrução de um espaço para "fugir da realidade e conhecer a felicidade completa", como enfatiza Veríssimo de Melo (1954, p. 203). Embora popularizado em outras produções pictóricas e literárias - o milenarismo e o paraíso de felicidade investigados por Jean Delumeau (2003) - de contextos e cronologias diversos, o traço singular aparece unido a certa curiosidade e incerteza dessa procedência, já que o poeta afirma em entrevista que a sua “'Viagem' nasceu de uma frase popular [...] 'só em São Saruê, onde o feijão brota sem chovê"” (SANTOS apud LESSA, 1984, p. 70), parecendo ignorar a origem medieval.

No rol de bons folhetos de Manoel Camilo, uma vasta produção Campose pertenças na bio/grafia de um poeta popular em diferentes métricas e dimensões pode ser contabilizada. Entretanto, no que toca a pertenças e discursos passíveis de sagrarem o artista no seu campo e de, talvez, possibilitarem ultrapassá-lo, instalam-se na sua faceta de editor e proprietário de uma folhetaria ${ }^{5}$, espaço de impressão e de comercialização de folhetos próprios, de versos cujos direitos foram comprados, ou de composições de colegas que contratavam seu serviço. Centrados nessa atividade do poeta, podemos ter contato com os bastidores do cordel, e, nas narrações de sua prática em entrevistas concedidas, percebemos as redes de relações e aquilo que apreendemos como uma espécie de sistema literário popular incipiente, cujos vértices estão constituídos por seus agentes - autores: editores proprietários/ compositores/versejadores; obra: folhetos impressos; público: leitor e/ ou ouvinte -, consumidores de folhetos. Essa organização parece propiciar o estabelecimento de um cânone que, apesar de assentado no campo da cultura popular, autocompreende-se como nacional, haja vista a declaração de Manoel Camilo ao manifestar a grandeza de um colega de profissão: "Leandro [Gomes de Barros], o maior poeta que o Brasil já deu" (SANTOS apud SARNO, 2006, p. 182). Essa enunciação dá mostras de certa alienação do poeta popular, tendo em vista que sua afirmação beira à ingenuidade ao desconsiderar uma tradição e uma literatura ca-

5 Manoel Camilo dos Santos teve contato com a editoração de folhetos em 1942, com algumas impressões realizadas na folhetaria Rebate. Em 1950, adquiriu máquinas e inaugurou um estabelecimento próprio, a Folhetaria Santos, localizada na cidade de Guarabira, seguindo carreira como compositor e editor-proprietário de folhetos. Seis anos depois, reinaugurou-a com um nome mais auspicioso "A Estrella da Poesia" (LESSA, 1984; SARNO, 2006, p. 177). 
nônica com a qual não dialoga e que talvez desconheça ${ }^{6}$, produção que se desenvolve em simultâneo, por vezes dela se vale, mas pouco se esforça para incluir as manifestações do cordel no seu seio.

Em outras investigações, já definimos o conjunto da obra de Manoel Camilo como uma criação que contraria a prática corrente da cantoria por se apresentar como "a expressão de uma voz que se dirige a um público amplo, abarcando desde o homem simples do interior da Paraíba, local onde foi emitida, até o sujeito capaz de legitimá-la, o leitor culto [...]" (NUNES, 2014, p. 116). Defendemos isso no que concerne à Geice Autobiografia do poeta (1979) publicada em Campina Grande, pela editora da Universidade Federal da Paraíba. Notamos que, enquanto agente do cordel, o artista ganha crédito simbólico no momento em que, em alguma medida, aumenta seu capital econômico e capital cultural, pois ascendeu da posição de poeta para a de poeta e proprietário de editora. Consciente do esforço que o reconhecimento pela classe culta reivindica, Manoel Camilo “empenha-se em falar a língua dos doutos, porém parece desconsiderar que a sua expressão popular possa ser interpretada como um arremedo". Nesse sentido, no arranjo da linguagem empregada, "vemos, na retórica, o elemento que dinamiza a sua poesia, capaz de dotar as criações de lirismo ou de jocosidade, mesmo quando o propósito é sério" (NUNES, 2014, p. 116-117). O maior sintoma disso está na percepção de que "talvez pela consciência dessa capacidade poética, o artista depreende seus traços diferenciais em relação aos seus pares e busca um distanciamento paulatino da essência do campo literário ao qual pertence" (NUNES, 2014, p. 129).

Em 1963, em entrevista a Geraldo Sarno, Manoel Camilo afirma ter publicado, ao longo da sua trajetória poética, cerca de 160 folhetos, de 8 a 64 páginas $^{7}$ (SANTOS apud SARNO,2006, p. 167). Desde o início da carreira, trilhou-a exercendo todo o tipo de autodidatismo: "não... não tive mestre pra nada [...] o que eu sei não tive mestre" (SANTOS apud SARNO, 2006, p. 173). Com exceção das lições do alfabeto, que lhe deram os pais, exemplo

6 Contemporâneo de escritores e estudiosos do popular como Mario de Andrade, Manuel Bandeira, Raquel de Queirós, José Lins do Rego, Guimarães Rosa e Carlos Drummond de Andrade, a hipótese de que lhes desconheça não parece exagero. Em entrevistas ou escritos de Camilo, o poeta popular não menciona quaisquer desses nomes, com eles não dialoga por intertextos ou outros recursos, o que mostra os efeitos da situação periférica da poesia popular, bem como de seus agentes.

7 Acerca disso, há uma incerteza em relação à autoria das publicações: como proprietário de editora, comprando a produção de artistas como João Melquíades Ferreira, publicou folhetos como editor-proprietário. 
de sua independência é o conhecimento de alguns ofícios como a marcenaria que lhe veio de forma autônoma e com o fim prático de ganhar o sustento: "pela forma de dinheiro/ e o aperto que sofri/ mesmo sem mestre aprendi/ a arte de marceneiro" (SANTOS, 1979, p. 19), anos depois, a atividade lhe deu subsídios para produzir as matrizes em xilogravura para capas de folhetos, os denominados clichês. Nessa mesma tendência ao autodidatismo é que lhe chega a habilidade para tocar viola e fazer jus à atividade de cantador e compositor de versos. Em tom autobiográfico, relata que, a partir do ano de 1936, segue essa profissão: “adotei a cantoria/ sem saber que a poesia/ seria meu ideial (sic)" (SANTOS, 1979, p. 19). Acerca desse aspecto, ressaltamos aqui as artimanhas do poeta, já analisadas por nós em outros escritos:

Campose pertenças na bio/grafia de um poeta popular

Camilo, quando se fixa no nível mais baixo, seja na pele de 'um pobre tão sabido' ou de 'um ignoto', demonstra sempre um impulso orientado para a ascensão" e, a partir dessa postura “constrói-se como um autodidata, que, se não alcança os doutos, julga-se apto a equipar-se artisticamente aos seus modelos culturais e literários (NUNES, 2014, p. 132).

A atuação como produtor de folhetos, mais especificamente como poeta-editor, contribui, na medida em que a página do cordel se converte na folha de jornal que o tipógrafo arranja à sua maneira ou a tela que o artista plástico preenche a seu modo. Assim, a peculiaridade de Camilo está em colocar em prática a autopropaganda como estratégia de mercado no espaço até então ocioso de grande parte dos folhetos. Isso é realizado de modo tão inédito que não aparece na escrita de nenhum outro colega e, assim, inferimos que é a liberdade enquanto editor-proprietário de folhetaria que lhe permite inovar no terreno conservador do cordel. As inovações tomam forma como para textos: notas de rodapé, pequenas notas no final do conteúdo versado, propagandas, inserção de textos reflexivos, laudatórios, etc., em contracapas e/ou páginas finais.

Esse se constitui como um ardil de Camilo, cujo efeito prova seu papel transgressor dentro do terreno do popular e mostra que, intuitivamente, o poeta-editor assimila algo que Bourdieu conceitua como illusio, em relação às regras da arte e as estratégias para consagração. Camilo percebe os princípios de funcionamento do campo literário do cordel, suas posições de poder, e investe nesse jogo. 
Os meios para validar e legitimar a sua atuação se fundam em etapas sucessivas, pois se começou a carreira como cantador e cordelista (ambas insatisfatórias), com o passar dos anos se lança às práticas da editoração; e, ainda, imprimem seus folhetos os versos convencionais. Nos espaços brancos de páginas ou nas contracapas, reproduz passagens narradas em versos, em prosa, fragmentos de entrevistas; ressalta a sua ilustre presença no campo do popular por meio de prêmios e distinções, autoelogios e, quando possível, reproduz as provas de sua legitimação.

Durval Muniz de Albuquerque Júnior destaca que “[...] no inte-

Geice rior dos grupos populares há aqueles que ocupam posições mais privilegiadas, que são mais fortes, que podem manter com as elites e com os demais grupos populares uma relação diferenciada, de maior destaque" (2013, p. 178). Camilo está representado na leitura crítica do historiador, visto que sua trajetória mostra a consciência de pertencer a um campo literário de menor prestígio, mas as relações que mantém com um grupo de prestígio impulsionam o poeta a alçar voos maiores.

É evidente que Manoel Camilo se reconhece como um agente importante no seu espaço de atuação e a confirmação dessa certeza aparece vinculada à autopropaganda. Essa prática se configura como um misto de tática e impulso que o poeta-editor dá vazão constantemente no espaço da contracapa dos folhetos (seus e alheios) para travar um jogo cordial, usado como estratégia para cumprir esse intento, valendo-se de meios e mediadores que possibilitem a ascensão. Para tanto, recorre aos contatos capazes de validá-lo: políticos, artistas influentes, professores, figuras que "exercem um domínio direto sobre o campo literário e artístico" (BOURDIEU, 1996, p. 66).

O poeta editor conhece as engrenagens que movem o campo que ocupa. Sabe que a folhetaria se mantém com a venda de cordéis, publicações consumidas por um público misto, composto pelos leitores, que podem ler de forma solitária ou constituírem-se como os "ledores"de um público semiletrado ou completamente analfabeto, por isso, dirige-se a esse público no espaço da contracapa. Em outro movimento, exalta o gênero cordel como um equivalente ao cinema e ao drama, portanto, destaca-lhe como um notável entretenimento. Desse modo, os textos impressos na contracapa - elemento paratextual desprestigiado por colegas de profissão até então -, estimula o consumo do gênero ao mesmo tempo em que mostra consciência das partes que lhe constituem: "Habitantes das cidades, vilas e sítios, divirtam-se lendo 
ou ouvindo ler os romances e folhetos de poesias populares, da autoria ou propriedade do poeta Manoel Camilo dos Santos" (equivalentes aos bons cinemas e dramas...)" (SANTOS, 19--., grifo nosso):

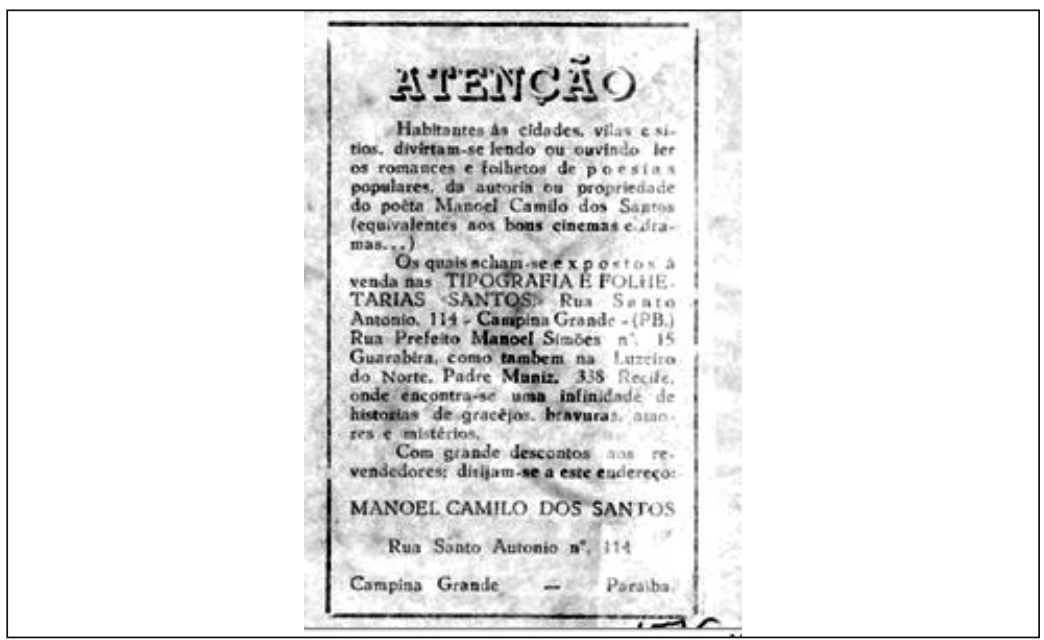

Campose pertenças na bio/grafia de um poeta popular

Figura 1: Contracapa do folheto Autobiografia do poeta Manoel Camilo dos Santos (19--.)

No uso original que Manoel Camilo faz do folheto, há a publicidade nos espaços menos usuais. Em Os dois amantes no cárcere (1954), de sua autoria, uma pequena nota após o acróstico final sugere ao leitor outra produção: a Autobiografia do poeta. Entretanto, este folheto, como poucos, traz a data abril de 1954 . No cruzamento de dados, a presença da data leva-nos a inferir que a leitura indicada, nesse caso, é o folheto de cordel homônimo às memórias que serão ampliadas e publicadaspouco mais de duas décadas depois: “ATENÇÃO: Não deixem de ler a Autobiografia do poeta popular Manoel Camilo dos Santos, para conhecerem todo passado da vida do mesmo a começar do ano 1905 à 1953" (SANTOS, 1954). 


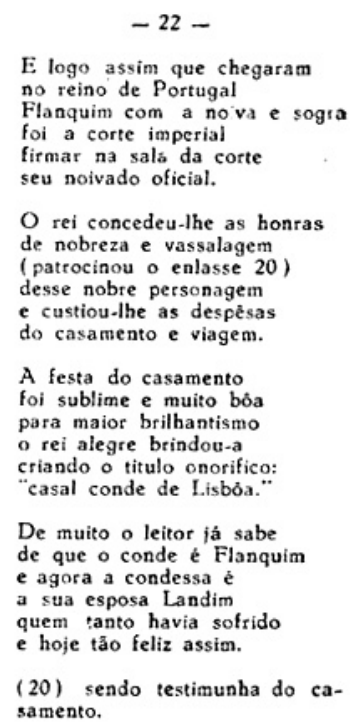

$-22-$

E logo assim que chegaram

no reino de Portugal

Flanquim com a nova e sogra

foi a corte imperial

firmar na saló da corte

seu noivado oficial.

$O$ rei concedeu-lhe as honras

de nobreza e vassalagem

(patrocinou o enlasse 20)

desse nobre personagem

e custiou-lhe as despêsas

do casamento e viagem.

A festa do casamento

foi sublime e muito bôa

para maior brilhantismo

o rei alegre brindou-a

criando o titulo onorifico:

casal conde de Iisbóa."

De muito o leitor já sabe

de que o conde é Flanquim

e agora a condessa é

a sua esposa Landim

quem tanto havia sofrido

e hoje tão feliz assim.

(20) sendo testimunha do casamento.

Geice

Peres Nunes

204
$-23-$

O ministro por ser máu morreu n'Alemanha atóa os jovens por serem dignos de intenção nobre e bôa casaram sảo donos e moram no seu condado Lisbóa.

Zorando no seu condado $>$ mbos agora se viam Zas horas meigas saudosas Os dois alegres sorriam Tam compensação das lagrimas Tucrarain o que bem queriam

Dom a velha eles viviam

$>$ qual os amava enfim

Zarido. mulher e sogra

-ntimamente era assim

rigados nessa uniāo

màu foi quem teve fim.

Campina Grande, 30/4/1954

ATENÇAO: Nâo deixem d e ler á Autobiografia do poéta popular Manoel Camilo dos Santos. para conhecerem todo passado da vida do mesmo a comeca do ano 1905 à 1953

Figura 2: folheto Os dois amantes no cárcere (1954)

Outra evidência das investidas para ganhar notoriedade no campo da literatura popular está no uso da contracapa do folheto Paulo e Jovelina ou a filha desobediante (1956). Para enaltecer autoridades políticas e religiosas, Camilo elogia instituições e agentes em uma mostra inegável de cordialidade. Depreendemos que, na sua compreensão, a relação entre poeta e instituições precisa operar na reciprocidade entre os elogiados e o reconhecimento (por meio da leitura) do poeta-editor:

A TIPOGRAFIA E FOLHETARIA SANTOS na pessoa do seu proprietário, vem de público parabenizar todo o povo do nordeste, pela realização do grande congresso dos bispos em Campina Grande, o qual fôra encerrado com a presença do Exmo. Sr. Presidente da República.

Na solene sessão de encerramento, D. Reverendíssimo Dom Hélder Câmara, arcebispo auxiliar do Rio de Janeiro, leu as 15 conclusões que chegaram bispos, arcebispos e técnicos, após a realização daquele certame, que durou 6 dias de sérias discussões, perante aos grandes representantes do comércio, indústria, agricultura e outros, tudo com o fim de proteger, melhorar e engrandecer o nordeste. 
O presidente da república, Sr. Juscelino Kubitschek, depois de um profundo e brilhante discurso tesceu (sic) considerações e prometendo dar-lhes cumprimento imediato...

Que se realize tudo o que foi aprovado n'aquele congresso: que se dê ao pequeno o direito de viver condignamente; que se louve a Deus e respeite as autoridades; que se trabalhe pela grandeza do bem e progresso d'esta Pátria; é o desejo e interesse d'esta pequena indústria, que tudo tem feito pela solidariedade e o bem coletivo de todos os brasileiros. Que Deus proteja aos senhores bispos e as todos os congressistas e lance uma benção especial ao Exmo.

Campose pertenças na bio/grafia de um poeta popular

Figura 3: Contracapa do folheto Paulo e Jovelina ou a filha desobediante (1956)

No que se refere à pertença a campos literários, o momento mais simbólico de Manoel Camilo dos Santos dá-se com a publicação de sua Autobiografia do poeta, no ano de 1979, com a chancela da editora universitária pertencente à Universidade Federal da Paraíba. A divulgação dessa conquista aparece registrada no verso da capa do folheto As aventuras de Pedro Quengo $(1981)^{8}$ e se o livro hoje nos dá mostras do orgulho de Camilo, o

8 Dentre as edições de As aventuras de Pedro Quengo, de Manoel Camilo dos Santos, encontramos impressões sem ano de publicação, muito recorrente na poesia de cordel e, datada, a edição de 1981, que referimos aqui. Impressão do mesmo conteúdo da carta ainda podem ser encontradas em folhetos como $O$ sabido sem estudo (1981) e Lourival e Terezinha (1981). 
cordel, pouco antes da referida publicação, conseguiu antecipar esse efeito no momento em que a confirmação da consagração lhe chegou e o poeta-editor a divulgou no seu principal veículo de publicidade. Na linha tênue entre a ingenuidade e a ironia, a prova do reconhecimento vem lado a lado com as aventuras de um pícaro nordestino, o personagem título do folheto, Pedro Quengo, sujeito "ladino, inteligente e sabido", que supera adversidades e, no final de suas aventuras, garante a riqueza e o reconhecimento pela esperteza. De modo análogo, Camilo, começando no cordel, dedicando-se à folhetaria, por volta de seus setenta e três anos, tem sua arte legitimada por uma editora reconhecida nacionalmente, e se mostra como o sujeito à margem a transpor espaços hegemonicamente estabelecidos: abrangendo (mais ou menos) 200 páginas, com 26 ilustrações e foi aprovado pela Universidade Federal da Paraíba e prefaciado por esta insigne Dra Francisca Neuma Fechine Borges. (O qual sairá muito breve). (SANTOS, 1981).

\begin{tabular}{|c|c|c|}
\hline Carta da Dr ${ }^{\mathrm{a}}$ Francisea Neuma F. Borges & & Auter $\because$ - Manoel Camilo dos Santos \\
\hline 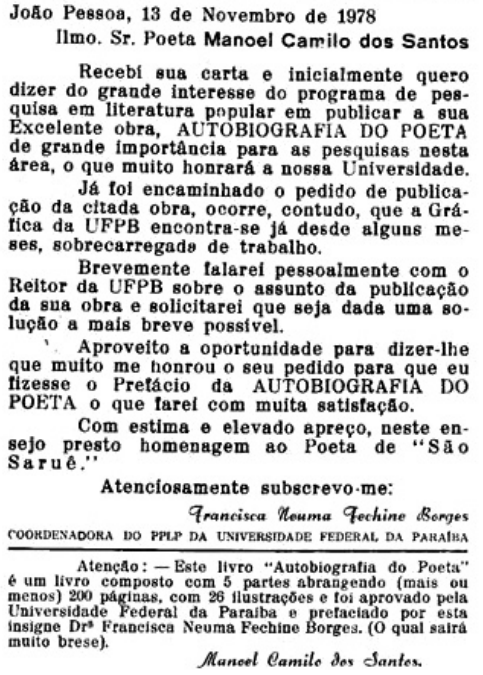 & $\begin{array}{l}\not{A} \\
\vdots \\
\vdots\end{array}$ & $\begin{array}{l}\text { As Aventuras de } \\
\text { - Pedro Quengo- } \\
\text { DEUS quando fez este mundo } \\
\text { deixou-o de tudo composto } \\
\text { um fraco, tolo e mofino } \\
\text { outro forte e bem disposto } \\
\text { uns ganham o pão com o saber } \\
\text { outros com o suor do rosto. } \\
\text { Esta historia se refere } \\
\text { a um homem que viveu } \\
\text { no Estado do Ceará } \\
\text { e no mundo nâo nasceu } \\
\text { outro ainda que tivesse } \\
\text { juizo igualmente o seu. } \\
\text { Pois ele desde pequeno } \\
\text { que era muito ladino } \\
\text { inteligente e sabido } \\
\text { quenguista, esperto etraquino } \\
\text { devido isto, uma alcunha } \\
\text { poseram-lhe desde menino. } \\
\text { Pedro Quengo justamente } \\
\text { foi o alcunha que lhe deram } \\
\text { devido ele ser quenguista } \\
\text { este apelido the poseram, } \\
\text { porém as sus quengadas } \\
\text { muitos lucros lhe trouxeram. }\end{array}$ \\
\hline
\end{tabular}

Figura 4: miolo do cordel As aventuras de Pedro Quengo (1981)

O tempo decorrido permite ver que o campo consagrado abriu uma brecha a Camilo, mas se manteve impenetrável para novas tentativas de conservar-se nos "salões que mais pelo que excluem que pelo 
que aglutinam, contribuem para estruturar o campo literário" (BOURDIEU, 1996, p. 69). Nesse caso, o próprio movimento da editora universitária, no final da década de 70, parece constituir o maior indício do impulso do "registrar antes de desaparecer". Ao mesmo tempo, cria um espaço de destaque, porém, sem subverter ou remodelar qualquer campo, visto que, se Camilo se consolida, é como peça de folclore. Vale ressaltar que observar essa cronologia possibilita compreender a publicação do livro de Camilo como fato associado aos estudos relacionados à poesia popular nordestina. Após a leva do final do século XIX, a segunda metade do século XX reúne uma nova série de estudos realizados tanto por investigadores estrangeiros, brasilianistas, como por nacionais, e se firma ao lado de programas políticos. Trata-se do despontar de uma perspectiva que vê a cultura popular como um emblema

Campose pertenças na bio/grafia de um poeta popular da cultura nacional, conforme desenvolve Maria Theresa Didier (2000, p. 35), num cenário em que o Nordeste parece se concretizar como um espaço de ambivalências, que se faz notar na ideia de subdesenvolvimento econômico e, em contrapartida, como a "resistência contra as influências externas e industrializantes" e por sua "aura de tradição preservada", "rico de cultura popular, fonte da possível originalidade da cultura brasileira".

Nesse sentido, fica evidente que, para os agentes capazes de legitimá-lo, o prestígio do poeta Manoel Camilo só se sustenta enquanto expressão do seu estrato social e artístico. A editora universitária publica a Autobiografia, mas adota a posição de conservá-la com faltas ortográficas, gramaticais e sem qualquer tipo de revisão. De modo tácito, afirma o lugar de Camilo: ainda que publicado em livro, em papel mais durável e de melhor qualidade, o seu campo, assim como o seu discurso, é o popular.

Na década de 1980, o cordel já havia perdido muito espaço entre a camada que sustentava sua importância enquanto arte popular despida de qualquer apelo folclórico e que conservava a sua relevância social como meio de entretenimento e difusão de informação. Arguto para inovar dentro do seu campo, nos 80, Manoel Camilo já não demonstrava a mesma perspicácia ou tenacidade para manter o vínculo com o campo da literatura consagrada, já se mostrava resignado e, talvez por isso, o esquecimento de o Livro dos sete episódios, o seu manuscrito com pretensões à publicação, seja algo tão sintomático a ponto de contribuir para o fechamento deste estudo. 
O Livro é organizado em sete partes, os "episódios" apontados pelo autor do manuscrito. Na sua forma, se sobressai o conteúdo datilografado e algumas correções e anotações a caneta, com colagens de letras de revistas e partes ilustradas de antigos folhetos. No que tange ao conteúdo, está composto por prosa e poesia. A prosa em tom intimista, em certos momentos, resgata passagens da vida pessoal, homenagens a benfeitores, assim como fora colocado em prática na Autobiografia. Entretanto, em muitos casos, sobretudo nos textos de caráter ficcional, Manoel Camilo encarna o contista, mas não se afasta do repertório Geice do cordel. Cria histórias de princesas, de heróis pícaros ou tragédias amorosas em forma de prosa, mas obedece à estrutura do gênero tão conhecido por ele.

Para além desses aspectos, em alguns poemas que constituem o livro encontramos a mais profunda melancolia do poeta em seus últimos anos de vida. Na memória recôndita, a prática da cantoria e da composição de versos ressurgem enlaçadas a lembranças afetivas: "Vi muita luz da candeia/Vi minha mãe fazendo renda/ E minha vó conversando/ Contando historinha e lenda/ Em casa de agricultores/ Vi diversos cantadores/ Desafiando em contenda." (SANTOS, 1985, p. 203). Enquanto agente desse sistema, a memória de Camilo revela a noção de consagração, mas também a percepção da perda: "No mundo dos trovadores/ Vi minha vida pomposa" (1985, p. 203), contudo, com o passar dos anos, o ressentimento pelo que perdeu ressoa nos versos: "Eu cantar como cantei/ Não houve mais quem ouvisse/ Abandonei cantoria/ E eu sorrir de alegria/ Jamais houve quem me visse" (1985, p. 203).

O tom persiste ao longo da composição poética em setilhas de sete sílabas, ritmo marcadamente popular, a narrativa flui na descrição do esquecimento que vive quando produz seus versos aos 78 anos, portanto, em 1983:

\footnotetext{
Do que vi, vivi e disse

Dos tempos primordiais

Só me restam as lembranças

E as saudades, aliás

Vivi épocas tão bendidas

Porém as cousas bonitas

Que eu vi não vejo mais.
} 
Em violas ou violões

Jamais peguei, é verdade

Mais aquela que foi minha

De tanta sonoridade

Se eu avistasse ela

Daria um banho nela

Com lágrimas de saudade.

Campose

pertenças na

Vejam aí a verdade

bio/grafia

No todo que escrevi

de um poeta

Nos setenta e oito anos

popular

E meio, que já vivi,

O bom desapareceu

Por isto que digo eu.

Não vejo mais o que vi. (1985, p. 204).

O velho estilo é retomado por meio da lírica de palavreado simples. Nos versos, o poeta recupera a linearidade do narrar e suas queixas ganham expressão com clareza: em 1985, o tempo áureo da literatura popular já desapareceu e a derrocada da carreira de Manoel Camilo é um fato. Esse caso não se constitui como algo isolado, mas como um processo consolidado com as novas mídias: o rádio e a televisão, algo que o poeta havia descrito em 1967:

A poesia baqueou-se muito. Há diversos fatores que levou a esse fim, viu: primeiramente a carestia, a alta da matéria prima, do papel, a tinta, da mão de obra; depois disto veio esses anos trapalhados, viu, ano chove muito, outro, seco. $O$ encarecimento do gênero alimentício, que concentrou o dinheiro do pobre, né.

[...]

Não pode comprar folheto, não sobra dinheiro para a compra de folheto. $\mathrm{E}$ depois disto me queixo muito também desse aborto de novelas pelos rádios. Agora há estação de rádio que tem por dia dez novelas. Isso baqueou muito a poesia, porque a poesia é quase isso, né?É. Aquela série de novela é quase a série de poesia, a mesma coisa. Por isso eu me queixo desses fatores. Mas espero que futuramente vá melhorar viu. (SARNO, 2006, p. 172, grifo nosso). 
Em meados dos anos 80, o poeta ainda não sabe, mas o seu Livro dos Sete Episódios não será publicado, poderá ser encontrado e lido poucas vezes, quem sabe por raros leitores. Na peleja desarmônica entre os campos da literatura culta e da popular, por vezes, seus vértices tenderão a se interseccionar - como em Ariano Suassuna ou Nei Leandro de Castro, autores que se valem do cordel em suas produções escritas -, mas as escarpas ásperas que separam esses terrenos não se suavizarão.

Ao finalizarmos, destacamos que o conjunto da obra de Manoel Camilo dos Santos e sua intrínseca relação com a vida do poeta-editor evidenGeice cia o que viemos denominando como bio/grafia, no sentido desenvolvido por Maingueneau. Nos entrecruzamentos entre escritos artísticos, etapas da carreira aliados ao tom subjetivo impresso nas composições em prosa e 210 verso fornecem elementos importantes para que o investigador organize fatos passíveis de expressarem, também, o lugar do cordel no cenário nacional (neste caso, abarcado pelo Nordeste e o Rio de Janeiro). Na carreira de Camilo, é a partir da retro alimentação entre bio/grafia que as pertenças ou exclusões a campos literários se tornam mais visíveis e, nesse sentido, as contracapas e seus conteúdos dialogantes com o entorno do cordel, também narram às abertas ou em negativo essa dinâmica do gênero.

Manoel Camilo, sujeito-poeta-editor, o "sabido sem estudo", em suas investidas para manter-se em conexão com o mercado editorial, caiu no esquecimento do público cativo do cordel nos anos 80. Essa percepção parece ser o motivo do despertar do saudosismo de sua entrevista, na qual descreve o ofício e a arte que lhe consagraram:

\footnotetext{
Fui cantador de viola, sou poeta, autor de alguns livros em prosa e rima, e se as letras tem sido minha meta, eu dou graças ao grande lá de cima, quatro vezes eu já fui premiado e três vezes também fui diplomado como poeta de um estro bem sadio e para mais honrar minha figura, sou patrono de uma casa de cultura do general Peregrino lá do Rio. (1985).
}

No fim da vida, como notícia de jornal, o poeta é encontrado residindo "numa humilde casa na rua Mato Grosso Bairro de Monte Castelo, pobre doente e esquecido pelos velhos 'amigos' de ontem". A obra que o imortaliza será sempre o folheto Viagem a São Saruê, do qual pouco se orgulhava. Desde 1985, a notícia não altera seu desfecho: notável na arte popular, mas invisível no panorama hegemônico da literatura brasileira. 


\section{REFERÊNCIAS}

ALBUQUeRQUe JR, Durval Muniz. A feira dos mitos: A fabricação do folclore e da cultura popular (Nordeste 1920-1950). São Paulo: Intermeios, 2013.

BOURDIEU, Pierre. As regras da arte. São Paulo: Companhia das Letras 1996.

Campose pertenças na bio/grafia

CURRAN, Mark. A presença de Rodolfo Coelho Cavalcante na moderna de um poeta literatura de cordel. Rio de Janeiro: Nova Fronteira; Fundação Casa de Rui Barbosa, 1987.

. História do Brasil em Cordel. São Paulo: Editora da Universidade de São Paulo, 2003.

DIDIER, Maria Thereza. Emblemas da sagração armorial. Recife: UFPE, 2000.

FRANCO JUNIOR, Hilário. Cocanha: Várias faces de uma utopia. Cotia, SP: Ateliê Editorial, 1998.

LESSA, Orígenes. A voz dos poetas. Rio de Janeiro: Fundação Casa de Rui Barbosa, 1984.

MAINGUENEAU, Dominique. O contexto da obra literária. São Paulo: Martins Fontes, 2007.

MELO, Veríssimo de. Pasárgada e São Saruê. In: Revista Bando. Ano V, vol. IV, n. 6. Natal, 1954.

NUNES, Geice Peres. A poética de Manoel Camilo dos Santos: um diálogo entre a poesia popular do Nordeste e a literatura culta. Tese (doutorado). Universidade Federal de Santa Maria, Programa de Pós-Graduação em Letras, RS, 2014, 238p.

PIZARRO, Ana. Introducción. In: PIZARRO, Ana (Coord.). La literatura latinoamericana como proceso. Buenos Aires: Bibliotecas Universitarias, Centro Editor de América Latina, 1985. 
SANTOS, Manoel Camilo dos. Autobiografia do poeta. João Pessoa: Editora Universitária / UFPb, 1979.

- O livro dos sete episódios de Manoel Camilo dos Santos. Cópia datilografada, 1985.

- Viagem a São Saruê. Ed. Propr. Manoel Camilo dos Santos, 19--. . As aventuras de Pedro Quengo. João Pessoa: MEC/PRONASEC

Geice Rural, UFPB, Funape, 1981.

Peres Nunes . Autobiografia do poeta. Campina Grande: Tip. Santos, 19--. . Os dois amantes no cárcere. Campina Grande. Ed. Prop. Manoel Camilo dos Santos, 1954.

- Paulo e Jovelina ou a noiva desobediente. Campina Grande. Ed. Propr. Manoel Camilo dos Santos, 1956.

. O sabido sem estudo. MEC/PRONASEC Rural, SEC/PB UFPB, Funape, 1981.

. Lourival e Terezinha. MEC/PRoNASEC Rural, SEC/PB, Funape, 1981.

SARNO, Geraldo. Manoel Camilo dos Santos. In: - Cadernos do Sertão. Salvador: Núcleo de Cinema e Audiovisual, 2006, p. 173-184.

- Recebido em junho / 2017

- Aceite em agosto / 2017 